\title{
Love Strong as Death: Towards Another Finitude
}

Agata Bielik-Robson 


\section{Essays}

Agata Bielik-Robson

\section{Love Strong as Death: Towards Another Finitude}

DOI:10.18318/td.2017.en.1.2

W hen, in late-modern Western culture, the belief in personal immortality begins to wane, the problem of finitude returns with the naked destructive force of the repressed. The late-modern "breaking of the vessels" indeed bears all the features of a major epochal catastrophe. The returning finitude breaks the Christian forms which, although refuted on the metaphysical level, survived in modernity as regulative ideas of cognition; their last exponent was Edmund Husserl whose whole phenomenological project still rested on the notion of an infinite "transcendental life." The newly rediscovered finitude destroys Christian conceptuality and liberates powers of negativity, which, since Schopenhauer and Nietzsche, result in a series of deaths: that of God, the cosmos, and finally, man. The "sting of death," once removed by Saint Paul, hits painfully again, by making - in Nietzsche's formulation - the desert of destruction grow ever wider. Finitude indeed delivers the final blow: it reveals the ultimate truth and damns all efforts to avoid it as futile and weak. With the truth-saying (veri-dictive) power of the ultimate sentence, it condemns to death all attempts to evade death. Death thus becomes the new alpha and omega, the new Real of the post-Christian world
Agata Bielik-Robson

- resides in Warsaw

and Nottingham. She

works at the Institute of Philosophy and Sociology of the

Polish Academy

of Sciences,

and is Professor

of Jewish Studies

at the Department

of Theology

and Religious

Studies, University

of Nottingham. Her

research interests

encompass

subjectivity, theory

of literature,

and philosophy

of religion, with

special focus on the

Jewish heritage.

She currently works

on a book Another

Finitude. Religion

of the Finite Life

in Freud, Rosenzweig,

and Derrida. Contact:

abielik@ifispan.

waw.pl 
turned into ruins: the melancholy waste-land of the Benjaminian ponderacio dolorosa, which transforms into one great Golgotha, the hill of the "naked skull" - as well as the entropic chaos of Blanchot's permanent disaster, the ill-starred, irreparable désastre. ${ }^{1}$

In this broken reality, it seems only natural to think about finitude in thanatic terms. Since the word "finitude" derives from finis, and finis is death, then finite life must be primordially a being-towards-death. The Heideggerian Dasein is the first paradigmatic realisation of this new vision in which Endlichkeit, newly rediscovered after a millennia of Christian repression, redefines human existence by focusing on its inevitable end. Death, the solitude of dying, and the authenticity of this terrifying Je-Meinigkeit, in which Dasein grasps itself as finite and thus finally de-fined, create the new affective horizon of late-modern philosophy. It will be now dominated by anxiety and care, Angst und Sorge: the negative "moods" of the subject constantly referring to its own lonely end. From this time on, the late-modern line of thought inaugurated by Heidegger will always insist on the isolated experience of authenticity as the anticipation of Dasein's solitary death.

But is this the only way in which to think contingency and finitude? There is, perhaps, an alternative which works through the problem of finitude differently: not under the auspices of death, but of love. While Heideggerian philosophy links finitude to thanaticism, and thanaticism to authenticity, in which Dasein cares always and only about its own being, this other thought, which chooses love instead, links finitude to the care of others: to the Hebrew ideal of the intense love relation between neighbours.

\section{New Contingency}

In Minima Moralia, Theodor W. Adorno recommends that we look at the world from the vantage point of redemption which allows us to see it as potentially happy and satisfied, yet without sublating its finitude. A responsible use of compassionate "despair," which we feel towards the suffering of all contingent beings here and now in their unredeemed and distorted state of things, should consist in the disinterested care for their finite condition: it is precisely this caring sentiment, this "felt contact," which complements, but also motivates, our knowledge. Adorno does not call this affect explicitly "love," but this light without which the technical skill of philosophy remains blind can only be conceived as the loving affect for the fellow creatures:

1 Comp. Walter Benjamin, The Origin of German Tragic Drama, trans. John Osborne (London: Verso, 1998), and Maurice Blanchot, Writing of the Distaster, trans. Ann Smock (Lincoln and London: University of Nebraska Press, 1986). 
The only philosophy which can be responsibly practiced in face of despair is the attempt to contemplate all things as they would present themselves from the standpoint of redemption. Knowledge has no light but that shed on the world by redemption: all else is reconstruction, mere technique. Perspectives must be fashioned that displace and estrange the world, reveal it to be, with its rifts and crevices, as indigent and distorted as it will appear one day in the messianic light. To gain such perspectives without velleity or violence, entirely from felt contact with its objects - this alone is the task of thought. ${ }^{2}$

This messianic affectivity, in which love lends light to critical knowledge, emerges for the first time in Saint Paul. In his First Letter to Corinthians love appears as the perfect affect for an imperfect world. And if love alone is perfect within a created reality, it is because it has a unique capacity to anticipate the perfection of a redeemed future state of things:

Love is patient, love is kind. It does not envy, it does not boast, it is not proud. It does not dishonour others, it is not self-seeking, it is not easily angered, it keeps no record of wrongs. Love does not delight in evil but rejoices with the truth. It always protects, always trusts, always hopes, always perseveres. Love never fails. But where there are prophecies, they will cease; where there are tongues, they will be stilled; where there is knowledge, it will pass away. For we know in part and we prophesy in part, but when completeness comes, what is in part disappears. When I was a child, I talked like a child, I thought like a child, I reasoned like a child. When I became a man, I put the ways of childhood behind me. For now we see only a reflection as in a mirror; then we shall see face to face. Now I know in part; then I shall know fully, even as I am fully known. And now these three remain: faith, hope and love. But the greatest of these is love. (1 Cor. 13)

Both these recommendations refer to an alternative affective horizon surrounding the notion of finitude: not deadly fear, but love which grasps the finite without trying to "dishonour" it. In this non-thanatic vision, contingency appears in a different light: it is not just the negative - the miserable transience given over to the destructive power of time - but also not just the positive to be left as it is. The perfect affect for the imperfect creation contains a good dialectical tension which does not allow love to passively affirm the

2 Theodor W. Adorno, Minima Moralia. Reflections on a Damaged Life, trans. E. F. N. Jephcott (London: Verso, 2005), 247. 
contingent existence: contingency, having no ultimate reason for being the way it is, opens itself to the possibility of transformation. At the same time, love does not condemn contingency to the shame of illegitimacy: it does not plunge it into the "dishonour" of a lesser being whose destiny is to merely pass away in the lower spheres of emanation. Its "despair" is active, not vanitative.

Love, therefore, is the affect perfectly attuned to the contingent existence which constitutes, as Freud would have it, its first object choice. Love does not look for Grund, the Heideggerian reason justifying contingency, but, precisely because of that, it does not treat contingency as statically given in its ontic status quo. Love is not a contemplative affect which orients itself towards the absolute and immutable; "it is not proud," which means that it operates horizontally, without "dishonouring" anything it encounters in the sublunary world. Unlike the Platonic Eros, which only temporarily chooses contingent beings in order to abandon them for the sublime heights, PaulineAdornian love fully accepts creatureliness in its transient condition. The term “creatureliness" - Franz Rosenzweig's Kreatürlichkeit - does not appear here accidentally: love as the perfect affect maintains within the created world the satisfaction of the Creator, who himself commented on his work - ki tov, "and it was good." Love, therefore, is the trace of transcendence within the immanent reality: it watches over creation and attempts to "complete" it, by pushing it towards creatio continua here and now. The non-sublime acts of earthly messianism are the daily works of neighbourly love which, in its passion of relationality, "connects all."

This passion of relationality is the opposite of the affective position dominated by fear and anxiety. The Song of Songs talks about love that is as strong as death (azeh hamavot ahavah), which also means that love is as strong as fear. Psychoanalytically speaking, love and anxiety are the interchangeable affects which constitute two different forms of the same libido: the indefinite, unique, and simultaneously excessive human drive. Freud introduces his own version of the Herderian anthropological difference: while animals possess instincts with their well-defined goals and destinies, human beings possesses only drives: the pulsational Sturm und Drang, which does not have its orientation established a priori and because of that can connect with everything and nothing at the same time. When this excessive libido chooses nothing, it disperses into a halo of anxiety, a non-concrete and non-objectified fear which troubles the psyche with a notorious sense of unfulfillment and detaches her from the world of objects. The anxiety dominated psyche plunges thus into solitary depression and melancholy.

In his studies on dementia precox, Carl Gustav Jung analyzes anxiety as the libido which has withdrawn from the world and does not choose any object in its stead; in all cases of depressive withdrawal, Angst comes forward as the 
affective sign of isolation and the lack of relation, which often expresses itself in the loss of speech. Unable to connect libidinally with any object, including the self, the "dement" falls into a mute stupor which makes him dead while alive. ${ }^{3}$

Love as the passion of relationality occupies the opposite affective pole. Its passionate will to cathect everything without "dishonouring" it (St. Paul again) orients itself towards all elements of reality which it tries to grasp in the net of intense relations. From this perspective, language itself would be the opposite of demential muteness, but also, as such, a derivative of the loving affect: the "living speech" (Rosenzweig's lebendige Sprache) connecting the self with all that surrounds it - the being-here of $D a$-sein with the being-there neighborhood of Fort-sein - appears to be the libidinal bedrock of language in which all can be bound to all. Thus, just as Gothean love "connects all," so does language. In its libidinal passion for relational binding, love, which "does not boast and is not proud," and language, which strikes up far-reaching connections between designates, would be one and the same thing.

Love strong as fear: this peculiar equivalence does not refer to the content of affect, the way it was wrongly understood by St. Augustine who, as we shall soon see, identified love with death. It refers merely to the formal - or, better, energetic - aspect of affect, where life-giving love and death-bringing fear emerge as two forms of the same human libido, its indeterminate excess. The libido constantly oscillates between fear, in which the psyche withdraws from the object-cathexes and falls into dead silence, and love, in which the psyche encounters and binds objects thanks to "living speech." The human libido, therefore, always transcends the animal link with being determined by instinctual needs: it is characterised either by a lack of relation to anything or by the passionate excess of relationality, which would like to cathect and connect everything.

Yet, the relation between love and language grows more problematic once language begins to emancipate itself from its affective source. Although love, as Rosenzweig has it, strives to "pace the orbit of the creation," it is also strictly nominalistic: it can choose its objects only "one by one" and never via general categories. Language, on the other hand, swiftly detaches itself from the concrete thing and, rather like the Platonic Eros, chooses the "icy abstraction" of general ideas, with their sublime aloofness towards anything

3 Comp. Carl Gustav Jung, Symbols of Transformation: An Analysis of the Prelude to a Case of Schizophrenia (London: Routledge, 1967).

4 Franz Rosenzweig, The Star of Redemption, trans. William W. Hallo (Notre Dame and London: University of Notre Dame Press, 1985), 235. 
sensuous and concrete, ${ }^{5}$ where the original affect which gave birth to speech, possible only between the two living singularities, dies. Love thus simultaneously gives rise to language and subverts it, by constantly "breaking the wholes" - this is how Rosenzweig puns on the kabbalistic shevirat ka-kelim, by turning it into shevirat ha-kolim - the aim of which is to once again nominalize the general abstractions and turn them back towards the contingent. The living, nominalistic, affective source of speech undermines language as an abstrct system and does not allow it to close upon itself in the hermetic realm of Platonic ideas. The living relation which "connects all" can thus never be simply identified with the linguistic structure where the connection ossifies into a systemic reference.

Love not only simultaneously creates and subverts language. The loveaffect for the world also changes the perception of contingency itself, by subverting the traditional negative approach to transience, temporariness, and finitude, upheld by most orthodox religions and philosophies. Philosophy has always defined the contingent as something merely possible, that is nonnecessary: it can come into existence but does not have to. Contingentia does not possess its sufficient reason which Leibniz regarded as the minimal condition of a being worth its name - that is, a being that is better than nothing. Hence still in Hegel, contingency as such is pure negativity close to nihil, which must be forged into rational necessity: the "reduction (Abkürzung) of all immediate content of experience"6 is the Hegelian task of philosophy.

Yet, in the world where all contingency would be eliminated for the sake of rationally grounded necessity, love would become simply spurious and inoperative. This is why in Hegel's system, love is only a transitory stage used by the cunning of reason which strives towards its ultimate goal: freedom as necessity made conscious. Hegel makes room for love solely on the level of familial ties where it develops the first ties; later these ties will be handed over to reason which will give them the final form of systemic necessity. Thus, similarly to language, which tends to forget about its living/loving source and freezes into an abstract sublime structure, a philosophical system can also forget about love by seeing in its acts merely a camouflage for the works of reason. To attempt to recover the true meaning of contingency, therefore, equals the deconstructive attempt to recover the proper meaning of love as to recall Saint Paul again - a perfect affect for an imperfect world, lying at the bottom of our linguistic/cognitive activity.

5 Comp. Theodor W. Adorno, Negative Dialectics, trans. E. B. Ashton (London and New York: Routledge, 2004), 4 .

6 Georg Wilhelm Friedrich Hegel, The Philosophical Propaedeutic, trans. Arnold V. Miller (Oxford: Blackwell, 1986), 11. 


\section{Active Love}

To see the world from the standpoint of redemption is to wish to change the world in such a manner that it becomes as close as possible to the messianic "slight adjustment" within creaturely reality.? Unlike philosophy, which speaks the idiom of rational necessity and the Hegelian "reduction of contingency," messianic thought regards redemption as yet another - slight but decisive - transformation of the contingent, which does not change its ontological status. Due to this manoeuvre, contingency does not become eternal and immutable, absolute and infinite; it is still a finite transient being, yet happy and satisfied in its condition. Unlike in Hegel, therefore, contingency does not jump into the Kingdom of Necessity, but also, unlike in Giorgio Agamben, it does not remain "irreparable." ${ }^{8}$ The truly recovered contingency is neither necessary, as in the last reckoning offered by the philosophical Owl of Minerva, nor beyond reparation, as in the Agambenian melancholy gaze.

Love precludes passivity towards which these two above approaches gravitate, despite all the differences between them. For Hegel, activity is, in fact, merely a Schein, an appearance which hides the truly operative rational laws of history, whereas for Agamben, contingency makes sense only as eternally "irreparable," that is, only when passively contemplated from the point of view which resigned from all messianic practice of "mending the world," in other words the exact opposite of the Adornian perspective on redemption. Yet, to see the world through the light of redemptive love means to see it as an arena of action: being which has no sufficient reason to exist is also a being which does not have its pre-established telos, so it can be fashioned according to love's will. Part of the redeeming force of love lies precisely in this radical c o n v e r s i o n: in turning the vice of negativity (lacking ground and justification) into a virtue of chance (a positive futuristic project of a better being). Here, contingency is neither a veil for necessity nor an object of passive contemplation, but offers itself instead as an infinite plasticity: an unfinished work still open to an ongoing creatio continua.

This, however, is not the plasticity of chaos, where contingency is "let loose" and abandoned to the "ontology of accident." Love for the contingent world is driven by Adornian ethical "despair" which responds to the suffering and tries

7 This term, coined by Walter Benjamin, appears in his essay on Kafka: Walter Benjamin, "Franz Kafka," in Illuminations. Essays and Reflections, trans. Harry Zohn (New York: Schocken Books, 1968), 134.

8 Comp. Giorgio Agamben, The Time That Remains: A Commentary on the Letter to the Romans, trans. Patricia Dailey (Stanford: Stanford University Press, 2005).

9 Comp. Catherine Malabou, Ontologie de l'accident: Essai sur la plasticité destructrice (Paris: Editions Léo Scheer, 2009). 
to prevent it. It does not see the suffering as the mysterious "irreparable" kernel of existence, but merely as a "clash" or, in Spinoza's terms, a "bad encounter": a wrong set of elements which collide instead of cooperating which could be repaired with one messianic "slight adjustment," mit einem geringen Zurechtstellen. This, for Adorno, is precisely the Archimedean point of support which allows one to move the whole globe, as well as the ultimate criterion of all serious thought: the suffering of the contingent being which is, just as contingency itself, never necessary. Contingent suffering, unnecessary by principle, thus opens to change, adjustment, transformation, or - simply - work. ${ }^{10}$

The Hegelian tradition considers work as the derivative of fear, more specifically, the fear of death. Unlike the Master, who does not fear death and looks negativity straight in the eyes, the Slave is in the grip of mortal anxiety: he is forced to work only because he fears death from the hand of the Master. "The fear of the Lord is the beginning of all wisdom," says Hegel, paraphrasing the sentence from the Book of Job: this is also the beginning of work and the civilisational transformation of nature. ${ }^{11}$ In his early theological works, young Hegel still experiments with the idea of love only to abandon it at the stage of the Phenomenology of Spirit, where he rejects it as a passive and ineffective sentiment. The Christian community, which he describes in "Christianity and Its Fate," realizes the Pauline ideal of love with a swiftness of a "pistol shot," and then rests on its affective laurels: instead of working, that is transforming natural reality, the Christian Gemeinde turns out to be satisfied and lazy in its sectarian seclusion. Lulled by the vision of advancing redemption, the members of the Christian sect do everything hos me, "as if," lovingly waiting for the apocalypse which will end time, while being lies there untouched as an indifferent lump of matter which only blocks the quick access to the realm of immortality. Hegel, who, in his private notes, called himself somewhat immodestly the "Aquinas of the Protestant world," cannot agree with such a triumph of passivity and holy laziness: as all Lutherans, he wants a theological justification of work.

And Hegel indeed succeeds in his endeavour, but under the aegis of a different religion which he changes as if imperceptibly, until Alexandre Kojève

10 In Negative Dialectics, in the all-telling chapter "Suffering Physical," Adorno insists on maintaining the non-theoretical and non-conceptual moment of compassion as "the moving forces of dialectical thinking": "The smallest trace of senseless suffering in the empirical world belies all the identitarian philosophy that would talk us out of that suffering [...] The physical moment tells our knowledge that suffering ought not to be, that things should be different Woe speaks: 'Go'": Adorno, Negative Dialectics, 202-203.

11 Georg Wilhelm Friedrich Hegel, Phenomenology of Spirit, trans. Arnold V. Miller (Oxford: Oxford University Press, 1977), 117. 
reveals the hidden trumps of his cunning theological game. According to Kojève, the new Hegelian religion consists in the revelation of death, since only fear of death can be the source of work: first slavish, then more and more autonomous. More and more, but never fully so. Members of Western civilisation can work only under coercion fuelled by the fear of losing their life, first because of the direct external threat coming from the Master, and subsequently because of the internalised drive towards self-preservation. The source of work, therefore, is the traumatic revelation of pure negativity: the deadly anxiety of the contingent being who knows that he is issuing inevitably into death. ${ }^{\mathbf{1 2}}$

Yet, if we try to look differently at contingency and finitude, we also gain a new understanding of the idea of work. Perhaps, we do not even have to go beyond - or against - Hegel in order to find a theological justification for what Kierkegaard used to call "the works of love."13 The anti-Kojèvian and more Kierkegaardian reading of Hegel was offered by Emil Fackenheim in his Religious Dimension of Hegel's Thought, which discusses the Hegelian variant of Judeo-Christianity as a religion of the active transformation of the world. According to Fackenheim's interpretation of Hegel, Christianity - unlike "pagan" religions regarding reality in terms of the necessities of fate - is the first religion of radical contingency. It perceives the world not as an "iron cage" which can only be escaped by mystical contemplation, but as the Pauline "passing figure" which, precisely because of that, is infinitely malleable. For Hegel, Pauline transience/passing is merely a reverse of the radical plasticity and malleability of the contingent being which can "pass" in its figure passively, but can also be actively "trans-figured": transformed by the Spirit itself which penetrates matter and works through it from within. In Hegel's system, therefore, contingency is a necessary moment in the plan of creation: "According to Hegel's theory, contingency itself is necessary without qualifications. On account of the necessity of the Notion there must be contingency in the world." ${ }^{14}$ Conceived as such, love, incarnated by the all-active, all-reaching, and all-penetrating Spirit (der angreifende Geist) has nothing in common with the simple escapist negation of the contingent realm:

Comp. Alexandre Kojève, Introduction to the Reading of Hegel. Lectures on the "Phenomenology of Spirit" Assembled by Raymond Queneau, trans. James H. Nichols, Jr., ed. Allan Bloom (New York: Basic Books, 1969).

13 Comp. Soren Kierkegaard, The Works of Love, trans. Edna Hong (New York: Harper Perennial Modern Classics, 2009).

14 Emil Fackenheim, The Religious Dimension of Hegel's Thought (Chicago: University of Chicago Press, 1982), 115. 
But faith by itself - the pristine faith of New Testament - only begins the confirmation. The believer who first hears the good news of the transfigured world exists in a world still untransfigured. Therefore, to begin with, he can only be in this world and not of it, negating it like Stoics and Skeptics. But the quality of his negation differs from theirs. He does not flee from the world, abandoning it to the control of untransfigured wordliness. Rather, he must dispute that control, and indeed, radically 'invert' the world with all its untransfigured values. Only when this inversion has become wholly actual will the divine confirmation of the human have penetrated the whole of the human being [...] Hegel's Christianity will be not New Testament Christianity, but rather the life of a church only initiated by New Testament faith. This life will be [...] of the modern Protestant rather than of the medieval Catholic church. Even the life of the Protestant faith will be fragmentary unless it is in creative interrelation with secular life [...] The life, death, and resurrection of Christ has initiated a process which seeks completeness until an infinite, transcendent heaven has descended to a finite, transfigured earth. (Fackenheim, 143; my emphasis)

On this reading, contingency is not being reduced to necessity, just as the immediate living concreteness is not to be sublated into "icy abstraction" of the ideal concept. On the contrary, contingency itself becomes necessary as such: as a maleable "figure of the world" which offers itself to the continuous transfiguration, until it "paces the orbit of creation" and completes the "work of love."

\section{Neoplatonic Ero-Thanatos}

It does not really matter here which of these two interpretations - the deathoriented one offered by Kojève or the love-oriented one offered by Fackenheim - is truer to the spirit of Hegel's system. What matters is the conceptual nexus which emerges with the latter, Judeo-Christian, reading: active love - agape/ahavah - aiming at the radical transfiguration of contingency which for the first time finds fully positive theological justification. What also matters is that this nexus locates itself on the opposite pole to Greek heritage whose main concepts depart from the ambivalent affinity between Eros and Thanatos.

The thinkers who first pointed to this difference were Denis de Rougemont in his Love in the Western World, but also, quite independently, Hannah Arendt in her doctoral dissertation on St. Augustine, written a decade earlier, 
in the 1920s. Just as de Rougemont criticizes Plato from the Christian/Pauline position, Arendt objects to the Neoplatonic framework of Augustinian Christianity, while evoking the alternative, Hebrew, version of love, which cannot be accommodated into the Ero-Thanatic mode of Plato's theory of sublimation. Both share the opinion that such love is, in fact, merely a $\mathrm{T} h \mathrm{~h}$ a $\mathrm{n}$ t o $\mathrm{s}$ in $\mathrm{d}$ i s g u i s e: a thinly masked death drive which invalidates the finite dimension of our worldly existence, making no room for the love of the other as the concrete living singularity.

According to de Rougemont, the Western world cannot be understood without a thorough analysis of the concept of love. But also, because love is here the key concept, it is almost impossible to define. The word "love" comprehends the vast plethora of phenomena which seemingly have nothing in common: from the simplest carnal desire (libido), through sublimated forms of romantic love (eros), up to the disinterested neighbourly love which Christianity decided to turn into the main social tie (agape). For de Rougemont, a self-professed Catholic, it is the latter form of love which is most precious and worth preserving and, at the same time, most endangered. De Rougemont perceives the greatest danger to the notion of agape/ahavah in the increasing domination of eros: the sublimatory kind of passion which Western culture has dubbed as romantic love.

According to de Rougemont, romantic love, which favours "affective misfortune," did not emerge only in Romanticism, but much earlier: in the era of the "waning Middle Ages" (to use Johan Huizinga's title), when the Cathar heresy spread through the south of France and the Church sent against it the new-fangled Dominican Order, with Saint Thomas on the frontline. Aquinas would soon attempt to refute the Cathar type of the Gnostic dualism, by creating the last Catholic system based on one grand premise - that being is good (ens et bonum convertuntur). This re-affirmation of the biblical thesis, God's ki tov [and it was good] was directed against the raise of the Manichean mistrust towards the world, which tended to perceive being as the creation of a lesser - or even openly evil - archon. The Manichean Cathars abhorred matter, as well as all affairs of flesh, and subordinated their extremely ascetic life to the principle of pure spirituality, which, as de Rougemont demonstrates, is nothing but the principle of "death in life," where death becomes the gate to the higher form of a non-carnal, pneumatic, but also solitary form of living:

Eros $[. .$.$] requires union - that is, the complete absorption of the essence$ of individuals into the god. The existence of distinct individuals is considered to be due to a grievous error, and their part is to rise progressively till they are dissolved in the divine perfection. Let not a man attach himself to his fellow-creatures, for they are devoid of all excellence, and in so far 
as they are particular individuals they merely represent so many deficiencies of Being. There is no such thing as our neighbour. And the intensification of love must be at the same time a lover's askesis, whereby he will eventually escape out of life. ${ }^{15}$

Here love not only is not opposed to death (as in The Song of Songs), but leads straight to it: it wants death as the ultimate liberation allowing one to "escape out of life." Eros and Thanatos flow into one another, by forming a higher spiritual synthesis: "love and death, or mortal love" transforms into the "love of death" (de Rougemont, 43). It is, therefore, not Jacques Lacan who discovers the death-wish as the secret reverse of all our erotic longings: he takes it directly (and admittedly so) from the Provencal troubadours for whom "the consolation of death is the seal of the only possible marriage that Eros was ever able to wish for" (191). De Rougemont, who together with Lacan attended the celebrated Hegelian lectures of Alexandre Kojève in Paris in the 1930s, indeed anticipates the later Lacanian thanatic inversion of desire: according to his analysis, "the language of passion can be accounted for on the view that mind comes before matter because it expresses, not the triumph of nature over mind, but an encroachment of mind over instinct" (167). His findings also perfectly coincide with Kojève's thanatic reading of Hegel who, due to this manouevre, becomes inscribed into the Gnostic lineage of pure spirituality which can always encroach over matter thanks to the absolute power of death: "Suffering and understanding are deeply connected; death and self-awareness are in league [...] On this alliance Hegel was able to build his general theory of mind and history" (51).

Unlike Kojève and Lacan, however, De Rougemont sides with St. Thomas (the original Aquinas of the Catholic world) and his emphatic "affirmation of existence," deeply convinced that the conflict with the Catharist form of spirituality is far from finished or solved. Once liberated, the Gnostic spirit of negation is to stay and prepare the coming of the new Ero-Thanatic era of modernity - even if all the cities of Albi have been reduced to the ground and all Cathar heretics have been burnt on stakes. It is to stay true above all to the form of romantic love which begins as Provencal courtly love for la belle dame sans merci.

This is not a love for any concrete living human being with whom one would like to spend their real life here and now. It is rather a love for a derealised, disembodied, and dehumanised absolute which becomes purified of all signs of life and thus transforms into an immaculate representation

15 Denis de Rougemont, Love in the Western World, trans. Montgomery Belgion (New York: Harcourt and Brace, 1940), 65-66 [my emphasis]. 
of death. To love the idealised la belle dame sans merci from Chretien de Troyes's poems means to desire death by a slightly roundabout route: to court Thanatos itself, only thinly disguised as Eros. As de Rougemont says about Tristan and Iseult, the most celebrated Breton romance, which till nowadays remains a paradigm of highest romantic transports, the love that unites the heroes is, in fact, "a passion for the Night and triumphs in Death which transforms passion from within" (de Rougemont, 25). To love this way means to love death, negation, and self-destruction, but it also implies the incapacity to endure life with all its inevitable imperfection, contingency, and frustration. Romantic love, which, in the conditions of early modernity, reiterates the Manichean irreconcilability with being, demands absolute perfection and reorients the desiring gaze towards the non-existent: the original Night of nothingness, which remains unsullied by the impurities of life.

Therefore, "the most beautiful is the object which does not exist." This saying of Zbigniew Herbert, opening his Study of the Object, ${ }^{\mathbf{1 6}}$ derives directly from the Gnostic lore of absolute negation, which de Rougemont tried to refute. No wonder that Herbert's verse did not find acceptance in the eyes of Czesław Miłosz who, himself a Catholic and advocate of the Thomist affirmation of being, scolded Herbert for paying lip service to "this scoundrel, Mallarmé," the poet whom Miłosz regarded as the literary epitome of the Gnostic type of nihilism. ${ }^{\mathbf{1 7}}$ Just like de Rougemont, Miłosz believes that there is nothing more dangerous existentially than love for "the beauty which does not exist" and that such form of the romantic Eros, merely thinly masking the destructive impulses of Thanatos, leads us away from the necessary recognition of our contingency and finitude. In its longing for the impossible and unattainable, paradigmatically represented by the cold and impersonal belle dame sans merci from Provencal poetry, the romantic Eros is nothing but a disdain for the innerworldly; it is thus the very opposite of Pauline love which is patient and kind; "bears all things, believes all things, endures all things" (1 Cor. 13:1-13). Agape loves by affirming the finite and the frail; it keeps close to the non-ideal finitude, convinced that one can only love what is marked by imperfection. The romantic Eros, on the other hand, does not bear and endure anything in its impatient longing to get out of the earthly condition crowded with the noisy multitude of beings into the Herbertian "uncreated world" where "no one is admitted." It accepts nothing, while making this very nothing a secret

16 Zbigniew Herbert, The Collected Poems, 1956-1998, trans. Alissa Valles (New York: Ecco, 2008). on Samuel Beckett, parallel to his attack on Mallarmé, in The Land of Ulro, trans. Louis Iribarne (New York: Farrar, Straus and Giroux, 1981). 
object of its passion; it detaches itself easily from any concrete object in order to seek mystical transport and annihilation in the sublime infinite.

Having criticised Neoplatonic Ero-Thanatos, de Rougemont leans towards this different - Pauline - affect: love for contingency, capable of an "active affirmation of being,"18 not despite but because of its finitude. The part devoted to Pauline agape bears the characteristic title: "Beyond Tragedy" - that is, beyond the influence of the Greek topos of thanaticism. And, had he not inscribed Hegel into the Gnostic lineage before, his own positive proposition would have sounded in perfect accordance with Fackenheim's interpretation of the Phenomenology of Spirit:

There is a new happiness beyond tragedy. A happiness which reminds of the old one, but it does not belong to the figure of the world, because it transfigures the world. (Ibid., 321)

This new promised happiness, however, which would allow the contingent being to feel satisfied in its finite condition, is now hard to be found. For de Rougemont, the crisis of the Western world consists precisely in the demise of the capability to love others/neighbours caused by the repression of agape, gradually replaced by the affected cult of Neoplatonic-Romantic Eros-Thanatos, which negates the finite by longing for the infinite. And although himself a devout Christian, Rougemont frankly admits that Christianity is not without fault here. For it is Christianity after all, which gave every individual a faith in her personal immortality and thus promised a "true life" beyond "this life," no longer limited and exposed to the dangers of finitude. The Christian desire, therefore, nolens volens bears a strong similarity to the Neoplatonic-Romantic Eros, just as the post-Christian desire which, modeling itself after romantic love, craves for the nocturnal "object which does not exist." They all lack attachment to the horizontal dimension of life inhabited by real others and both share an excessive passion for the vertical dimension of escape which Neoplatonic writers call regressio: away from this world and back to the pleromatic union with the Infinite, which knows no difference and no harm. ${ }^{19}$

18 De Rougemont, Love, 268.

19 See, for instance, Bernard de Clairvaux, commenting on The Song of Songs in "On Loving God," in Bernard of Clairvaux. Selected Works, trans. Gillian R. Evans (New York and Mahwah: Paulist Press, 1987), 205: on man's journey towards the mystical union with God "every need of the flesh will vanish and fleshly love will be absorbed in the love of the spirit, and the weak human affections we have now will be changed into divine affections." Whereas, as de Rougemont rightly says, "agape, on the contrary, is not directed to a union that can only occur after life is over," de Rougemont, Love, 66. 


\section{Good Enough Love}

The issue of affective attachment to the world is the main tenet of Hannah Arendt's doctoral thesis, Augustins Liebesbegriff. Anticipating de Rougemont's critique, according to which the Western world has lost the faculty of agape, Arendt emphasizes the crucial moment in this process: the non-acceptance of finitude. She demonstrates this epochal change on the example of Saint Augustine. Caught in the terminological net of Neoplatonic thought, which defines love as a craving for the Infinite (appetitus), Augustine inevitably runs into trouble with his account of neighbourly love (caritas). For him, "life on earth is a living death, mors vitalis, or vita mortalis. It is altogether determined by death; indeed it is more properly called death."20 "The fearlessness is what love seeks" (Arendt, 11), which means that "the good, which can be understood only as a correlative to love defined as craving and which is unobtainable for mortal life, is projected into an absolute present commencing after death" (13). The final goal of love, therefore, lies beyond the world: "The 'good' of which man is deprived and which he therefore desires is life without death and without loss" (30).

Just like de Rougemont, Arendt contrasts Augustine's Liebesbegrieff with Saint Paul's concept of love by claiming that in the latter, "love is by no means a desire that stands in need of fulfillment" for "caritas contains its own reward" (31). This love never fails for it is perfect and finished, even as finite, and it will not change in the future world; as already accomplished, it is the sure messianic sign of the new coming community which will be run by love only. Moreover, Arendt continues, Pauline love does not depend on the Greek preconception of being that can only truly be when it is infinite and eternal. For Paul, the world that passes and all its transient parts do exist, for they are created as such - temporal and transient - by their Maker. It is not an internal quality of being, which determines "true being," but its source or its status as creatureliness; though transient, nondurable, and passing, a creature nonetheless exists, precisely as a creature is given (if not the "eternal gift of life") at least a certain lifespan. Creatureliness, therefore, is not a nihilized world of becoming in the Platonic sense of the word, since it enjoys its own fully affirmative way of existing, which is finite being; it is not infinity tinged with nothingness, but a separate mode of existence based on the positively conceived finitude which knows its own happiness and satisfaction.

For Augustine, however, neighbourly love is only a stage in the development of appetitus which, as all appetites, grows beyond the realm

20 Hannah Arendt, Love and Saint Augustine, ed. Joanna Vecchiarelli Scott and Judith Chelius Stark (Chicago: University of Chicago Press, 1996), 11. In The City of God 12.21 Augustine says: "If indeed it is to be called life, when it is really a death." 
of contingency and demands ultimate fulfilment in immortal life. This is why he can immediately inscribe the famous verses from Song of Songs "Set me like a seal on your heart, like a seal on your arm. For love is strong as Death, jealousy relentless as Sheol. The flash of it is a flash of fire, a flame of the Lord himself" - into the scheme of Neoplatonic mysticism:

Love itself is our death to the world, and our life with God. For if it is death when the soul leaves the body, how is it not death when our love goes forth from the world? Therefore, love is as strong as death. ${ }^{\mathbf{2 1}}$

Augustine's Liebesbegriff is thus wholly dependent on the thanatic structure of desire born out of fear and deprivation. In Augustine's view, love is indeed as strong as death, but only because it is essentially the same power, capable of taking the human soul out of this world. Arendt, inspired by Paul, understands this conclusion differently: not as the reaffirmation of the deep affinity between Eros and Thanatos, but as the opposition which points to the equal power of both adversaries. Since ben Akiva, one of the Talmudic founding fathers, insisted on introducing Shir ha-shirim into the canon of the Hebrew Bible, this erotic poem served as an allegory of the passionate elective love between God and his people, which then was taken over by the Church Fathers who reinterpreted this allegoric love in Neoplatonic mystical terms (as in Augustine). Yet, for the Jews, who remained mistrustful of mystical transports (Arendt included), the Song has always been a canvas for the meditation on neighbourly and creaturely love: the love which does not seek God but orients itself towards all neighbours/creatures who happen to be next to one.

Without love, all those neighbours/creatures - the multitude of contingent beings who just happen to spring into existence next to us - would indeed be "like those who go down to the pit" (Psalms, 28) or like the Paulian "clanging cymbals," that is, nothing but automata briefly animated by a mechanical trick. Love, however, bestows the spectacle of creaturely being with autonomous and autotelic meaning. Love's goal is not to give those creatures life after death, but to give them life before death: to offer them active and affirming light, thanks to which - as Franz Rosenzweig claims - they will be able to see their life again and say ki tov, "yes, it is good." Love lifts existence

21 Augustine, Tractates on John's Gospel 65.1; my emphasis. While commenting on this fragment, Arendt issues a great warning, which is also Rosenzweig's deep concern: "The Christian can thus love all people because each one is only an occasion, and that occasion can be everyone. Love proves its strength precisely in considering even the enemy and even the sinner as mere occasion for love. It is not really the neighbour who is loved in this love of neighbour - it is love it self," Arendt, Love, 97; my emphasis. 
to the second power in which the ephemeral phenomena of the contingent being are raised to the dignity of "essences." 22 Thus, if David's Psalms are so full of fervent invocations to God who gives life, it is not because of the future possibility of life immortal, but because of the fear of death in life, in which the contingent creature recognizes its negative fate and "becomes like those who go down to the pit." To have faith in active love means to believe in another finite life which will be able to live - instead of waiting for its end in the fearful mode of imitatio mortis.

As Franz Rosenzweig demonstrates in his Star of Redemption, whose second book is wholly devoted to the "grammatical analysis" of Song of Songs, the poem is, in fact, about a disenchanted love - yet, disillusioned for its own good. Indeed in the beginning, love strives towards God, but is rejected and, thanks to this fortunate frustration, comes back to the creaturely world where the one great unattainable object (like the Lacanian objet $A$ ) becomes diffused into a metonymic sequence of small objects (objets a), namely, the neighbours. In the psychoanalytical terms of D.W.Winnicott, the Rosenzweigian God resembles "a good enough mother" who gently rejects the passionate possessiveness of her child and teaches it a lesson of "positive frustration."23 For Rosenzweig, "disenchantment makes love only stronger [...] Love cannot be other than effective. There is no act of neighbourly love that falls into the void,"24 because it is precisely the disenchantment which shows love its proper trajectory: away from the elusive Grand Object and towards the contingent beings of the outside world, which just happen to be next to one in the most direct vicinity (Platzhalter). In consequence, love - the active affect turned away from the false path of sublimation and back towards contingent beings - assumes the task of "connecting all" and "pacing the orbit of creation" (Rosenzweig, 235).

Christianity's role in this development seems highly ambivalent: torn between Pauline agape and Neoplatonic Eros, the Christian doctrine oscillates between the recognition of the creaturely mode of being and its violent rejection. Christian thinkers have a natural tendency to misread the main line of Shir ha-shirim as "Love s tro nger than death." 25 This characteristic

Rosenzweig, The Star, 239.

Comp. Donald Woods Winnicott, Playing and Reality (London: Routledge, 1971).

Rosenzweig, The Star, 269.

For instance, Werner Jeanrond, in his recent monograph on the Christian theology of love: "All we need is love. God is love. Love is all that matters. Love is stronger than ... d e a th": Jeanrond, A Theology of Love (London: T\&T Clark, 2010), 1; my emphasis. Actually, it is the very first paragraph! 
misreading very aptly depicts the shift from the Jewish covenant to the Christian one: it expresses the ultimate triumph of faith, hope, and love over the earthly misery of suffering and death. The Jews, however, read it the way it is written: "love as strong as death," which builds simultaneously a correspondence and contrast between the two antagonists. The correspondence here consists in the fact that both, love and death, are the markers of finite life; the contrast, on the other hand, lies in a radically different interpretation of finitude. Love does not function here in a Christian way, that is as an index of grace that anticipates the state of future life eternal. Love functions here as another way of seeing our finite life; not in a vanitative-melancholy manner of Seinzum-Tode, a deplorable mode of a being destined to perish from the moment of its inception, but in a more "bearing-enduring" approach in which finitude, the universal condition of a creaturely life, becomes lovingly accepted, asserted, and affirmed. As Rosenzweig often emphasizes, Judaism is a "religion of the finite life": a religion which does not desire infinity and immortality, always more life-after-life, but powerfully desires life-in-life which will not fear the verdict of death and will be able to love itself as finite. "Love Thy neighbour as Thyself": the commandment, which for the first time appears in the Hebrew Bible, formulates the new rule of ahavah-agape as the active love which chooses for its objects only finite, contingent, and imperfect beings.

For love is indeed strong as death. Not stronger - but also not weaker. Just good enough. 